\title{
The Effect of Transformational Leadership on Company Innovation Culture: Perspectives from the Service Sector of an Emerging Economy
}

\author{
Irene Stella Agyenim-Boateng \\ P. O. Box CE 12101, Tema, Ghana \\ E-mail: stella.a-boateng@vra.com \\ Kyeame Ghansah (Corresponding Author) \\ Accra- Ghana \\ E-mail: kyeameghansah@gmail.com
}

Received: June 22, 2019 Accepted: July 23, 2019 Online published: August 12, 2019

doi:10.5296/ijhrs.v9i3.15255 URL: https://doi.org/10.5296/ijhrs.v9i3.15255

\begin{abstract}
Focusing on the importance of innovation culture to the growth of firms, the study examined the effect of transformational leadership on the innovation culture of firms in the service industry in Ghana. The study further assessed the moderating role of organizational learning capability and market dynamism. A sample of 210 employees in the telecommunication, banking and insurance, tourism and hospitality sectors were surveyed. A quantitative research approach was employed to test the various relationships. The findings indicated that transformational leadership had a significant and positive relationship with innovation culture. The findings further revealed that the relationship between transformational leadership and innovation culture was positively enhanced by market dynamism. Organizational learning capability which had two dimensions, that is, interaction with external environment and dialogue had a partial moderating effect on innovation culture. The study provides executives with critical insights on the need to allow employees to make some decisions where necessary and also trust in their decision and not always control the work tightly from the top; as such micromanaging could have adverse impact on the firm's innovation drive and culture. The researcher contributes to extant literature by finding the moderating role of market dynamism and learning capability on the effect of transformational leadership and innovation culture in an organisation specifically in the service industry of an emerging country.
\end{abstract}


Keywords: transformational leadership, innovation culture, organizational learning capability, market dynamism, service sector, emerging economy

\section{Introduction}

In recent times, organizations have been forced to transform their old processes and products to meet the changing needs and preferences of customers. Firms are achieving competitive advantage with the advent of new products and services and even ideas. Regardless of type of industry a firm is in, innovation in products and services has become an important driver of business success for any firm (De Brentani, 2001). Firms which are not able to keep up with globalisation and its new trends are not able to survive in a changing market business environment (Betancourt \& Gautschi, 2001). Innovation, either in the form of product, process, marketing or systems have become an important instrument of global competitive advantage. In Ghana, and even worldwide, the service industry has become very important due to its contribution to the economies of countries.

The service industry which is one of the booming sectors of the Ghanaian economy ranges from telecommunications to banking, insurance, hospitality, media and tourism among others. It is key to note that the booming nature of the industry has its attendant challenges, some of which are talent acquisition and retention war, effective employee engagement, satisfaction of customer demands and also the need for sustainable competitive advantage which then makes it imperative for innovation to be the core DNA of the individual companies in the industry. Research has indicated that $70 \%$ of the GDP of developed economies is from the service industry; making it a key component in the development of creativity and innovation (Ostrom et al., 2010). This case is not different from emerging countries like Ghana. The success of firms in the service industry has been attributed to the levels of innovation (Ostrom et al., 2010). We could infer that innovation plays an important role in the competitiveness and performance of firms (Chapman, Soosay \& Kandampully, 2003).

Innovation researchers have identified that corporate leaders have the ability to impact the performance of employees to deliver innovative and creative results (Shalley \& Gilson, 2004). This has been one of the attributes of successful leaders (Zhang \& Bartol, 2010; Wang, Rode, Shi, Luo \& Chen, 2013). For example, Amabile, Schatzel, Moneta and Kramer (2004) in their study ascribed that, the behaviour of corporate leaders is a determinant of employee creativity and innovation in a work environment. For an organisation to develop innovative capabilities, there is the need to consider the role of the leader (Jung, Chow \& Wu, 2003). Notably, this assertion focuses on transformational leadership style because, there has been extensive research for example (Gumusluoglu \& Ilsev, 2009; Wang \& Rode, 2010; Wang et al., 2013) which found out that, transformational leadership style is a stronger determinant of innovation and creativity. In the study of Jung et al (2003) transformational leadership was found to highly encourage innovation culture and further support employees to exhibit their creative mindset and ideas for the growth of the organisation.

Again, the service industry in Ghana today deploys all manner of technology as a means to differentiate themselves in the competition but they make less effort in understanding that to make innovation a differentiator, it goes beyond an event or a product or technology - rather, 
it is driven by the top management as a culture that shakes and moves the very fabric of the organization to get all hands on deck. Past researchers have focused on the individual organizational sectors within the service industry but not taking on board the service industry in Ghana as one holistic research ground focusing on leadership styles as having a relationship with the promotion of innovation culture. This calls for a research into this; but more importantly, the study is premised on the fact that, investigations into the factors affecting innovation have been the concern of numerous empirical studies (e.g. Anderson, Potočnik \& Zhou, 2014; Molina-Castillo\& Manuera-Aleman, 2009) and there has been some researches which have established relationships between transformational leadership and innovation culture (Sattayaraksa \& Boon-itt, 2018; Xeniko, 2017). Research has shown that under certain market conditions, firms are able to innovate and also learn new ways of doing things. In support of the above assertion, some researchers (Yayavaram \& Chen, 2015; Hedge \& Shapira, 2007; Tanriverdi, 2005) have established that, for firms to be innovative, it is crucial that the resources of the firm are properly managed; and this depends on the ability of the firm to learn from external environment. Learning capability has been identified to improve organizational creativity and innovation (Li, Wei, Zhao, Zhang \& Liu, 2013; King, 2009; Tsoukas \& Mylonopoulos, 2004), but despite the numerous empirical reviews establishing direct effect of transformational leadership and innovation culture, the moderating effect of learning capability and market dynamics have been non-existent.

Firms innovate in order to adjust to the needs and preferences of customers and also be able to learn new knowledge for prudent management of their resources. This is because innovation culture happens in response to change in the internal and external environment (Gomes \& Wojahn, 2017). The relationship between leadership and innovation could be more complex than what was previously imagined.

Accordingly, we explored the following research questions:

RQ1: What is the effect of transformational leadership on company innovation culture?

RQ2: What is the moderating role of market dynamism and learning capability on the effect of transformational leadership on innovation culture in an organisation?

\section{Review of Literature, Theory and Hypotheses Development}

\subsection{Leadership and Innovation Culture}

Leadership sets the tone for innovation. Lack of leadership vision and drive will place the concept of innovation culture in the basket of mere rhetoric. Whether new interventions in the organization will increase efficiency and give best offerings to the customer or not will depend largely on the measurable elements that are evaluated through the leadership. Leadership as defined by Robbins, Judge and Breward (2003), is how a group of people who have been given authority are able to influence another group of people to deliver results. In support of this, Chemers, (1997) states that this group of people in the higher echelon always have more power which they are expected to exercise to harness the skills of others to accomplish common tasks. Leadership is tasked to provide appropriate direction, motivate and solicit the commitment of the people to buy into his (the leader's) vision (Gallagher, 
Goodyear, Brewer \& Rueda, 2013). The ability to make followers believe that the leader possesses superior knowledge of the situation, greater wisdom to cope with the unknown, or greater moral force which is also key to leadership. On the other hand, the concept of innovation involves an effort to put forward purposeful creativity that can result in a positive change in an organization's economic, social and reputational potential in the eyes of its stakeholders especially consumers. Graham, (2008) indicates that innovation is about the implementation of new ideas which have the potential to cause the organization to increase its profitability and or market share. According to Krause (2014), innovation occurs when the whole process of identifying and taking control of opportune situations to inventions and development of ideas becomes a reality. In the view of Yeoh and Mahmood (2013), an idea becomes an innovation when it transforms from being an idea to a solution that a customer can attest to as having added value to his/her perspective. This was earlier buttressed by Burkus, (2011), that the ability to come up with new ideas is just the basic ingredient of innovation so until it is nurtured, developed and applied to bring value-add, it ceases to qualify as an innovation.

Innovation culture is the kind of work environment where leaders create the opportunities for employees to grow and be nurtured to think outside the box and apply same to situations with the view to achieving better results than the status quo would have typically produced. According to De Jong and Den Hartog (2007), it is that kind of environment where the way of doing things relate to providing support for the effort of those who think creatively and provide solutions that add economic and social value to knowledge, processes, products and service delivery. It is also seen to be a culture of collaboration among teams. Some researchers (Crossan \& Apaydin, 2010; Wang, \& Ahmed, 2004; Ahmed, 1998; Martins \& Terblanche, 2003) have identified innovation culture as a multidimensional construct, but there is no agreement concerning the determinants of the dimensions. The dimensions of innovation culture have been stated in literature to include the infrastructure to support innovation, environment to implement innovation, intention to be innovative, the operational level of the behaviors needed to influence the market and value orientation (Dobni, 2008).

Leadership style of top managers/leaders forms a critical component of the environment needed to implement innovation. Review of literature (see Jung, Chow \& Wu, 2003) suggests that, transformational and participatory leadership styles create an environment that support innovation. This is done through the promotion of active followership where organizations become breeding grounds for fresh ideas from all units and departments.

\subsection{Transformational Leadership}

Bass (1999), defined transformational leadership as a process in which leaders and followers raise one another to higher levels of morality and motivation. According to Kang, Solomon and Choi, (2015), transformational leadership is one of the most commonly and extensively researched areas of leadership. Interestingly enough, some researchers do not attribute any relationship at all between transformational leadership and innovation culture. What has become increasingly clear though with these researches is the fact that, as mentioned by Avolio and Bass (1988), researchers into leadership only interrogate the context within which 
transformational leadership can be most effective. According to Akbar, Sadegh and Chehrazi (2015), there are four key tenets of transformational leadership, popularly referred to as the 4Is. These are Individualized consideration, Intellectual stimulation, Inspirational motivation and Idealized influence.

Individualized consideration is where the leader considers the uniqueness of each of his/her followers and gives them individual attention through separate communication, specific workload allocations and relevant customized support. A transformational leader shows respect to his/her followers, giving every indication to them and others that they are valued members of the team. According to Horwitz et al; (2008), a transformational leader applies the individualized consideration concept to support his/her followers to develop their individual potential and recognize them for current performance. The strengths and developmental gaps of the individual followers are determined under this concept of Individualized consideration. The result of such determination is utilized by the transformational leader to assign roles and responsibilities to each individual follower with the aim of supporting their personal growth (Hoy \& Miskel, 2008).

Intellectual stimulation requires the transformational leader to tease out from followers the need to rethink to debunk some stereotypes and rather discover new solutions to organizational challenges. Fernet, Trépanier, Austin, Gagné \& Forest (2015) and Tonkenejad, (2006) mention that the leader does this by asking the followers specific questions which push them to rethink about working processes and the efficient ways to reengineer them. The leader presents the followers with existing challenges but re-framed so that they (the followers) can re-organize their thoughts to find different solutions to old challenges. There is no public ridicule or criticism of the followers if errors are detected. Followers are given the opportunity to showcase their creativity by finding innovative solutions to a problem. By this the followers consider themselves as being part of the problem-solving process. The transformational leader employs various emotional symbols to encourage the team members to go the extra mile, over and above their personal interests. The team and individual spirits are heightened by the leader's inspirational motivation. This creates the avenue for the team's optimism and enthusiasm to increase, pushing them to always look forward to future situations to prove themselves again. Northouse (2015) states that inspirational motivation improves the followers' understanding of the organizational mission and vision which are very fundamental to organizational innovation culture.

Lastly, for the concept of Idealized Influence, it describes leaders who become role models for their followers. According to Bigharaz et al, (2010); such leaders often set high moral and spiritual standards for their followers to strive to reach the height that they (leaders) have reached. Such leaders attract the admiration, respect and trust of their followers and the followers imitate them. The central core of this technique is the fact that it provides purpose and instils a sense of high standards in the followers.

\subsection{The Leader-Member Exchange (LMX) and Innovation Culture}

According to Lunenburg (2010), the fundamental principles of this theory is that organizational leaders categorize their employees into two main groups, those who form the 
In-Group or inner circle and the Out-Group who are outliers. In the view of Wayne, Shore and Liden (1997), LMX is premised on the foundation that these relationships between leaders and their team members are as a result of some physical or mental effort, information flow from each party, open communication channels, and a psychological or emotional bond between the two parties.

The LMX theory views the relationship between the leader and the team members on individual basis and each of these relationships can have different dimensions and focus. It is the aggregation of these individual relationships that culminate into an In-Group or Out-Group. LMX influences organizational outcomes, employee engagement and deliverables which have a direct bearing on the creation and promotion of innovation culture. It is critical to note that the type of relationship between the leader and the team members influence the quality of job outcomes. The relationship between an employee and his/her leader is akin to the lens through which the entire workplace experience is viewed. Ilies, Nahrgang and Morgeson (2007); Chen, Lam, \& Zhong (2007); point out that the In-Group members will have higher productivity, job satisfaction, motivation, empowerment, engagement and will be better behaved and ready to act innovatively.

The leaders deliberately and consciously invest more resources in this group members than the others. Basu, (1991) has supported the claim that there is a positive correlation between "leader-member exchange and innovation behaviour". So when the positive relationship exists, there is a high degree of the tendency of the leader winning the hearts and minds of the employees - they start thinking outside the box and break new grounds. On the other hand when they experience or perceive themselves as part of the out-group, they work-to-rule, become superficial, disengaged, less effective, frustrated and dissatisfied. Such employees care less about the fortunes of the organization and consider themselves as only hanging in there, usually as they wait for better opportunities outside of the organization. The result of that can also be devastating to the organization and no deep-seated innovation culture can thrive in that kind of environment.

This pre-supposes that the leadership style, behaviour and actions are impactful in driving innovation culture. Employees would like to perceive their leaders as treating them fairly, flexibly and firmly but with the freedom to deliver within their space. Clear leadership support for innovation will thus generate innovative behaviour because the climate of the organization is, more often than not, measured by the leadership behaviour/attitude. The degree of cordiality between employees and their leaders represents a key environmental influence in the work situation. Where the degree of cordiality is high, the employees believe their innovative behaviour will result in organizational performance gain with its antecedent recognition of their effort. It is important to state that, some leadership styles encourage knowledge sharing which leads to innovation but that is beyond the scope of this paper.

\subsection{Hypotheses Formulation}

\section{Transformational leadership and innovation culture}

It is important to note that some literature have it that certain variables may contribute to the 
extent to which transformational leadership may thrive in the world of business. Such variables range from start-up business environments to large and mature ones with different degrees of uncertainty, competitiveness, availability of resources, profitability levels, value system, agility of decision-making process/structures, turnaround time, the level of diversity and inclusiveness among the workforce and very critically, the closeness of the leader to the led.

Some researchers (such as Bass \& Riggio, 2006; Dvir, Avolio \& Shamir, 2002; van Knippenberg \& Sitkim, 2013), have established that critical situations including crisis, produce effective transformational leaders. Transformational leaders encourage employees to appreciate the importance of sacrificing their personal comfort and interest for the attainment of organizational goals. A number of researchers theorize that transformational leadership is linked to organizational performance (Para-González, Jiménez-Jiménez \& Martínez-Lorente, 2018; van Knippenberg \& Sitkim, 2013; Bass \& Riggio, 2006; Wang et al., 2005; Bass, 2003; Dvir, Avolio \& Shamir, 2002). Conceptually, it is argued that the visionary and inspirational skills of transformational leaders motivate followers to deliver superior performance (Nicholls, 1988; Quick, 1992) and others (e.g. Bain, Mann \& Pirola-Merlo, 2001; Scott \& Bruce, 1994) have found some relationship between transformational leadership and innovation culture. Jung (2001) also views managers as playing key roles in developing, transforming, and institutionalizing organizational culture. Jung, Chow \& Wu (2003) found out that transformational leadership by the top manager can enhance organizational innovation directly and also indirectly by creating an organizational culture in which employees are encouraged to freely discuss and try out innovative ideas and approaches. Along the same vein, Schein (1992) argues that as organizational founders and leaders communicate what they believe to be right and wrong, these personal beliefs become part of the organization's climate and culture. In summary, we could deduce that there is enough evidence to suggest that transformational leadership style impacts on innovation culture; but there have been inconclusive results to that effect. Based on this, the researchers hypothesize that:

Hypothesis 1: Transformational leadership has a positive effect on innovation culture

\section{The moderating role of Market Dynamism}

Market dynamism refers to the dynamics that happen within a given market environment. These changes can occur as a result of changes in technology, defined or undefined market structure, instability of market demands and intense fluctuations in resource supply (Jansen , George, Van den Bosch \& Volberda, 2006, Simon et al; 2007). According to Miller and Friessen (1983), market changes occur when the environment is volatile and unpredictable. When those situations occur, it becomes very challenging to clearly define market boundaries, or build sustainable market models or build sustainable structures around the stakeholders in the market to hold them constant, for example, customers, competitors and suppliers (Eisenhardt \& Martin 2000). During such times organizations become quite vulnerable from the external uncertainties. Such situations typically defy existing knowledge, strategies, policies, practices and activities the organization may have applied to achieve results in more stable times. 
Inspite of the difficulties organizations may encounter during such times, customer demands must still be met. It takes organizations with innovation culture to continuously find creative ways of improving and modifying their products and services to satisfy customers. If an organization which may be experiencing such market changes decides to continue to apply the same strategies, policies, procedure sand knowledge as it would have done in "normal" times, such an organization would be heading towards extinction. Where there are no such regular changes, the level of predictability ensures that organizations can follow a relatively clear linear path and not be heavily concerned about modifications in products and services (Eisenhardt \& Martin 2000; Schilke, 2014).

The researchers state that, increasing technological changes, globalization and stiff competition require organizations to pay critical attention to market structural dynamics and orientation. An organization that cannot comprehend the new orientation of its market cannot survive and as Kohli and Jaworski (1990 p3) define market orientation, it is "the organization-wide generation of market intelligence, dissemination of intelligence, across departments, and organization-wide responsiveness to this intelligence". This requires that the organization must understand the market dynamics and responsibly apply innovation to meet the demands to create organizational sustainability.

The market structure has a relationship to the concept of competitiveness. Where competition is tense, organizations with innovation in their DNA can survive. When the intensity in competition is low, innovation may not take centre stage as against when the intensity is high. Thus the speed of innovation is either heightened or slackened depending on the competitiveness of the landscape in the market structure. Persistent dominance of an organization in a market has the potential to affect the market structure. Where there is a clear tilt towards the heavy dominance of one organization against others, similar organizations within the sector then may consider either Mergers \& Acquisitions, capital injection and changes in shareholding structure. The market dynamism and competition give rise to talent flights as well. Organizational leaders have a responsibility to ensure that innovative practices are introduced into talent attraction, development and retention strategies as well as reward and recognition schemes and a generally welcoming work environment for employees. Such plausible innovative ways would have to be explored to situate the organization appropriately in the market where a change in a competitor's business model could impact the entire market structure. Competition in the market may be conceptualized as the rivalry between organizations in terms of pricing, product characteristics, and distribution strategy and customer service. However, a more recent and nuanced conceptualization is encapsulated in the ability to innovate within the customer space

The relationship between market dynamism and innovation culture has not been extensively researched into and the few studies which has somehow considered the moderating role of market dynamism have inconclusive results. For example, in a study by Kamasak, Yavuz and Altunaz (2016), they found out that the relationship between knowledge management and innovation capabilities of firm was stronger when market dynamism was high rather than when it was low. Also, Park and Ryu (2007) found out that when there is frequent market changes then technology commercialisation will have a positive impact on business 
outcomes.

The researchers hypothesize that:

\section{Hypothesis 2: Market dynamism will negatively moderate the relationship between transformational leadership and innovation}

\section{The moderating role of Organisation Learning Capability}

Learning capability according to Gomes and Wojahn (2017, p.165) is "the ability of an organization to process knowledge, i.e., the ability to create, acquire, transfer and integrate knowledge and, also, to modify the behaviour to reflect the new cognitive situation, with the aim of improving organizational performance". Similarly, Jerez-Gomez et al (2005, p.38) defines organizational learning capability as "a firm's capability to learn from internal and external sources and to adjust or modify its behaviour to reflect the new cognitive situation, with a view to improving its performance". The ability of a firm to understand and learn the tangible and intangible asset is very imperative to their competitive urge. Organizational learning helps firms to apply their knowledge to achieve competitive advantage by being innovative.

Learning capability has been conceptualized by previous researches as a multi-dimensional constructs (Alegre \& Chiva, 2008; Jerez-Gomez et al., 2005), which includes participative decision making, dialogue and teamwork, interaction with external environment, risk taking and openness and experimentation (Mbengue \& Sane, 2013; Camps \& Luna-Arocas, 2012; Jyothibabu, Farooq \& Pradhan, 2010). The openness and experimentation dimension is defined as "the extent to which new ideas and suggestions are attended to and treated sympathetically". This dimension relates to how the organisation adopt and treat new ideas and suggestions. Experimentation covers how the organisation seek for new innovative ways. Risk taking is also defined as "the tolerance of ambiguity, uncertainty, and errors" (Alegre \& Chiva, 2008, p.317). The risk dimension also relates to the ability of the firm to tolerate errors, uncertainty and ambiguity. Organizations should be able to accept mistakes and by doing so, promote learning. The ability of the organisation to take risk afford it the opportunity to be innovative. Also, the interaction with external environment is "the relationship that a firm maintains in its immediate environment. Chiva et al (2007) is of the view that, the relationship between the organisation and its environment involves receiving and sharing information and interactions of employees with the external environment and reporting of information from the external environment. Dialogue was defined by Kamasak et al (2016, p.236) as "a sustained collective inquiry or a basic process that enhances communication and allows people to see the hidden meanings of words". Dialogue helps in building understanding between parties. Dialogue facilitates communication and the presence of multifunctional work teams and free and open communication within work teams. For innovation to take place, firms need to break barriers to effective communication such as authoritarianism, centralization of power and hierarchical system; whiles the last dimension of learning capability, participative decision-making was defined by Alegre and Chiva (2008, p.37) as "the level of influence that employees have in the decision-making process". The researcher conceptualizes learning capability with the five dimensions. 


\section{Macrothink}

International Journal of Human Resource Studies

ISSN 2162-3058 2019, Vol. 9, No. 3

The researcher believes that learning capabilities of the firm plays a key role in the innovation process, this is because of the importance of the individual constructs of learning capability. For example, there has been extensive research on how learning capability positively affects innovation performance (e.g. Alegre \& Chiva, 2008; Jimenez-Jimenez \& Sans-Valle, 2011; Alegre \& Chiva, 2013), but none of these researchers has recognized the effect of transformational leadership on innovation culture taking into consideration the role of learning capability. The leadership of an organisation plays key role in promoting organizational learning and it will be important for find out the condition under which organizational learning capability affects this relationship. Based on the above review, the researchers hypothesize that;

Hypothesis 3: Organizational learning capability will positively moderate the relationship between transformational leadership and innovation culture

The researcher conceptualizes the hypotheses below:

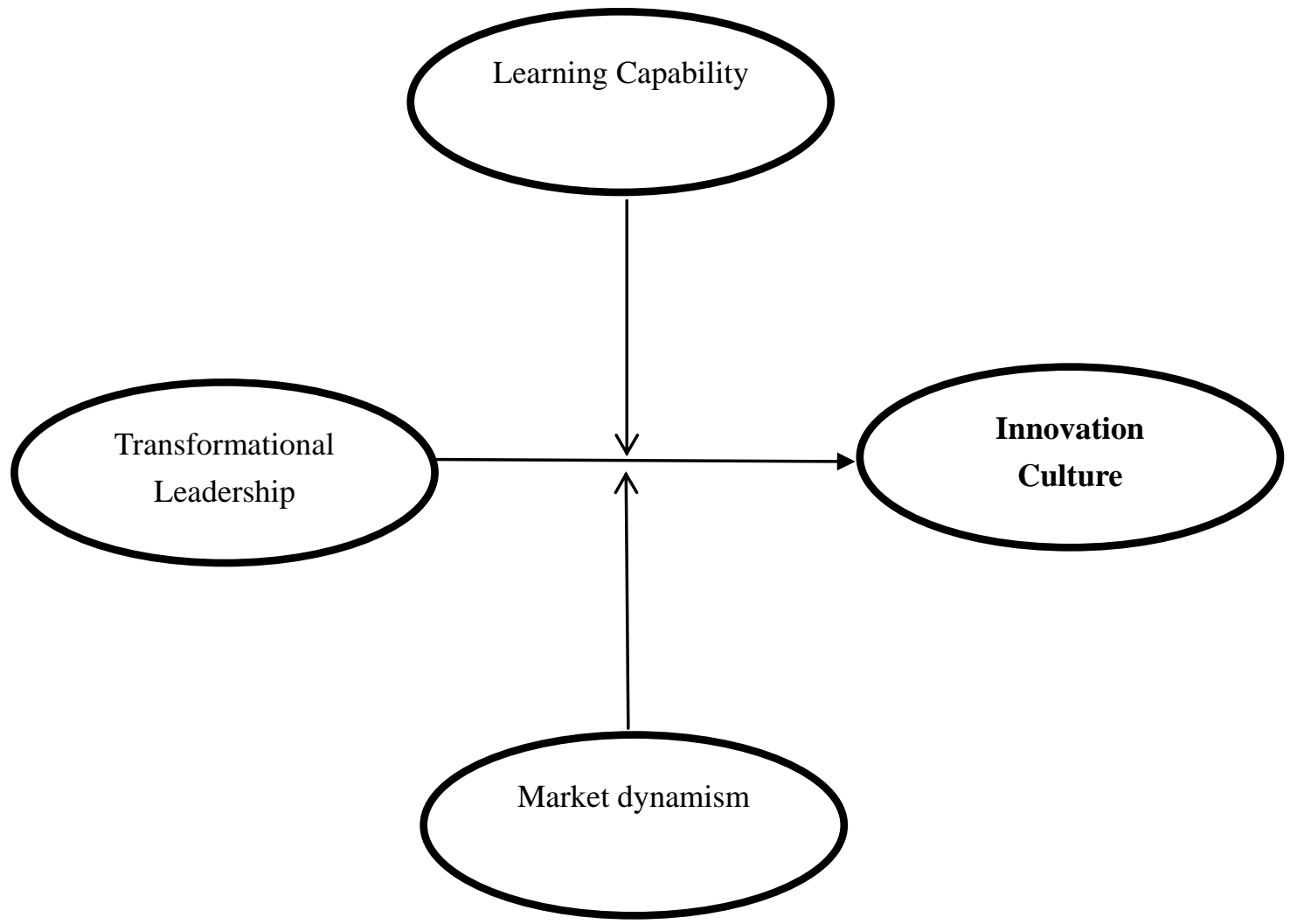

Figure 1. Conceptual model

\section{Research Methodology}

\subsection{Research Design}

Our research was conducted as a quantitative research study to establish the relationship between transformational leadership and innovation culture and more importantly, finding out 
the moderating role of market dynamism and organizational learning capability. Borg and Gall (1989) indicate that quantitative research deals with fairly large sample sizes and is devoted to the study of relationships between objects as they exist. In this case, the researcher assumes a passive stance and does not immerse herself/himself in the research. Information about the object of study is deduced by the use of statistical techniques of data gathering. This data is then analyzed and the results presented in numerical formats.

\subsection{Measures}

The study used the survey methodology which is in line with the positivist paradigm. Consistent with other previous studies on transformational leadership and innovation culture, a quantitative research approach using survey questionnaires was adopted. A multiple regression analysis was adopted and a multi-step process were adopted (Blankson et al., 2007). The scales used in the questionnaire were based on other measurements scales adopted from previous research on transformational leadership, organizational learning capability, market dynamism and innovation culture (Jaiswal \& Dhar, 2015; Wang et al., 2015; Alegre \& Chiva, 2008; Dobni, 2008). The questionnaire was designed into two parts. The first section was on the Likert scale type of questionnaire and they were anchored on $1=$ strongly disagree to $5=$ strongly agree. The second section was designed to obtain information on the respondents. The Likert scale question on Transformational Leadership was adopted from the study of Jaiswal and Dhar (2015) and was measured with eight items. Organizational learning capability was also adopted from the study of Alegra and Chiva (2008) which incorporated with fourteen items covering experimentation, risk taking, interaction with the external environment, dialogue and participative decision making. The questions relating to market dynamism was also adopted from Wang et al (2015) with six items, whiles the questions on innovation culture was also adopted from Dobni (2008) with nine items.

\subsection{Data Collection and Analysis}

Similar to other previous studies on transformational leadership styles and innovation culture (Keller, 2002; Jaiswal \& Dhar, 2015), the researchers adopted a threefold data collection process. A total of 30 firms in the telecommunication, banking and insurance, tourism and hospitality located in Greater Accra region of Ghana were contacted. To ensure their acceptance to participate in the study, a letter was sent to the top management of each firm about the objective of the research and also emphasised the practical implications of the study. Next, after the acceptance, questionnaires in sealed envelopes were sent to each firm to be given to the employees through convenient sampling approach. The questionnaire was given to their respective Human Resource Executives to be given to the employees. After three weeks a total of 400 questionnaires were shared to all the firms targeted. 250 were received but 210 were included in the analysis because the remaining had incomplete information and were thus discarded. In line with the specification of Bihani and Patil (2014), descriptive statistics, exploratory factor analysis and multiple regression analysis techniques were used to analyze the data collected and cleaned data. 


\section{1) Macrothink}

\section{Analysis of Results}

\section{Profile of respondents}

The descriptive analysis of the data showed that out of the 210 samples used for the analysis, $64.3 \%$ of the respondents were males whiles $35.7 \%$ of the respondents were females. In terms of the structure of the ages of the respondents, $1.9 \%$ were between the ages of 18-25 years, $31.0 \%$ were between the ages of 26-35 years, $51.9 \%$ were between the ages of 36-45 years whiles $15.2 \%$ were above 46 years. $23.8 \%$ of the respondents were junior level employees, $51 \%$ were middle level staffs whiles senior level staffs comprised $24.8 \%$. In terms of years of being in their current positions, $10.5 \%$ had been in their current position for less than a year. $40.5 \%$ had been in their current position for 1-3 years in the service industry, $33.3 \%$ had been in their current position for 4-7 years, and 7.6\% had been in their current position for 8-10 years whiles $8.1 \%$ had been in their current position for above 10 years of working experience. Further, $1.9 \%$ of the firms has employees of less than 20, whiles $33.3 \%$ of the firms surveyed had between 21-50 full time employees, $18.1 \%$ of the firms had between 51-99 full time employees whiles majority (46.7) of the firms had above 100 full time employees. Lastly, in terms of the years of existence of the surveyed firms, $6.2 \%$ of the firms had been in existence for less than 5 years, $4.3 \%$ had been in existence for between 6-10 years, $8.1 \%$ had been in existence for $11-15$ years, $9.5 \%$ had been in existence for $16-20$ years whiles $71.9 \%$ had been in existence for more than 21 years. The result is illustrated in Table 1

Table 1. Biographical information of respondents

\begin{tabular}{|c|c|c|c|}
\hline \multicolumn{2}{|l|}{ Category } & Frequency & Percentage $(\%)$ \\
\hline \multicolumn{4}{|l|}{ Gender } \\
\hline & Male & 135 & 64.3 \\
\hline & Female & 75 & 35.7 \\
\hline \multicolumn{4}{|l|}{ Age } \\
\hline & 18-25years & 4 & 1.9 \\
\hline & 26-35years & 65 & 31.0 \\
\hline & 36-45years & 109 & 51.9 \\
\hline & 46years and above & 32 & 15.2 \\
\hline \multicolumn{4}{|l|}{ Employment level } \\
\hline & Junior staff & 50 & 23.8 \\
\hline & Middle staff & 108 & 51.4 \\
\hline & Senior staff & 52 & 24.8 \\
\hline \multicolumn{4}{|l|}{$\begin{array}{l}\text { Experience in current } \\
\text { position }\end{array}$} \\
\hline & Below 1year & 22 & 10.5 \\
\hline & $1-3$ years & 85 & 40.5 \\
\hline & 4-7years & 70 & 33.3 \\
\hline & $8-10$ years & 16 & 7.6 \\
\hline & Above 10 years & 17 & 8.1 \\
\hline \multicolumn{4}{|l|}{$\begin{array}{l}\text { Years of being in the } \\
\text { organisation }\end{array}$} \\
\hline & Below 1year & 6 & 2.9 \\
\hline & $1-3$ years & 23 & 11.0 \\
\hline & 4-7years & 61 & 29.0 \\
\hline & $8-10$ years & 43 & 20.5 \\
\hline
\end{tabular}


Number of employees

Years of firm existence

$\begin{array}{lll}\text { Less than 20 employees } & 4 & 1.9 \\ \text { 21-50 employees } & 70 & 33.3 \\ \text { 50-99 employees } & 38 & 18.1 \\ \text { Over 100 employees } & 98 & 46.7 \\ & & \\ \text { 0-5 years } & 13 & 6.2 \\ \text { 6-10 years } & 9 & 4.3 \\ \text { 11-15 years } & 17 & 8.1 \\ \text { 16-20 years } & 20 & 9.5 \\ \text { Above 21 years } & 151 & 71.9\end{array}$

\subsection{Exploratory Factor Analysis (EFA)}

To identify the factors which are relevant in predicting innovation culture, the EFA was employed as data reduction strategy. Prior to the extraction of the relevant factors, the Bartlett test of Sphericity (Approx: $x_{2}=1828.343, d f=210$, Sig. 0.000) and the Kaiser-Meyer-Ohlin measure of sampling adequacy value of 0.836 (Chan \& Idris, 2017) confirmed that there were significant correlation among the variables to warrant the use of the factor analysis for further analysis. The researchers accepted variables with factor loading of 0.5 or greater and factors with Eigen values which were equal or greater than 1 for further analysis (Malhotra \& Birks, 2006; Hair et al., 2010). The extraction method used was the Principal Component Analysis (Hair et al., 2010). There were a number of cross loading of the initial 38 items to 21 items which explained $62.67 \%$ of the satisfactory variance. Based on the recommendations of Hair et al (2010), items could be dropped when they cross loading or have factor loading of less than 0.5 and in line with this, 18 items were dropped.

The researcher used varimax rotation in the EFA. The researcher used above 0.7 as the ideal level for the reliability of the scales. The 20 items loaded perfectly with 5 extraction. 'OLC' which was used to denote organizational learning capability had two sub factors and they were all used in the analysis. The first factor was denoted Transformational Leadership with 4 items. The second factor was Market dynamism with 3 items. The third factor was Organizational Learning capability (Interaction with external environment with 4 items and Dialogue with 4 items). Finally, the last factor was Innovation culture with 6 items. The internal consistency of the 5 factors were analysed using the Cronbach's alpha (Chan \& Idris, 2017). The results indicated that all the five factors were reliable between 0.726 to 0.876 . On the basis of this results, all the five factors were accepted for further analysis. Table 2 illustrates the factor loading and the reliabilities of the scales 
Table 2. Factor analysis results

\begin{tabular}{|c|c|c|c|}
\hline Factor and Items & $\begin{array}{l}\text { Factor } \\
\text { loadings }\end{array}$ & $\begin{array}{l}\text { Item-Total } \\
\text { Correlation }\end{array}$ & $\begin{array}{l}\text { Cronbach's } \\
\text { Alpha }\end{array}$ \\
\hline Transformational Leadership & & & .744 \\
\hline \multicolumn{4}{|l|}{ My supervisor... } \\
\hline Talks to us about his/her most important values and beliefs & .702 & .499 & \\
\hline Expresses his/her confidence that we will achieve our goals & .787 & 666 & \\
\hline Expresses his/her confidence that we will achieve our goals & .708 & .567 & \\
\hline Re-examines critical assumptions, whether they are appropriate & 665 & .445 & \\
\hline Market Dynamics & & & .726 \\
\hline Technological changes in our industry were unpredictable & .776 & .581 & \\
\hline The market competitive conditions were highly unpredictable & .829 & 601 & \\
\hline Customers' product preferences changed quite rapidly & 669 & .473 & \\
\hline Interaction with external environment & & & .793 \\
\hline $\begin{array}{l}\text { It is part of the work of all staff to collect information about what is } \\
\text { going on outside the company }\end{array}$ & 639 & .516 & \\
\hline $\begin{array}{l}\text { There are systems and procedures for information sharing outside } \\
\text { the organisation }\end{array}$ & .754 & .662 & \\
\hline $\begin{array}{l}\text { People are encouraged to interact with the environment: } \\
\text { competitors, customers, technological institutes, universities, } \\
\text { suppliers, etc }\end{array}$ & .717 & .636 & \\
\hline Employees are encouraged to communicate & .764 & .604 & \\
\hline Dialogue & & & .754 \\
\hline There is a free and open communication within my work group & .749 & .528 & \\
\hline Managers facilitate communication & .763 & .571 & \\
\hline Cross-functional teamwork is a common practice here & .750 & .604 & \\
\hline $\begin{array}{l}\text { Managers in this organization frequently involve employees in } \\
\text { important decisions }\end{array}$ & .830 & .518 & \\
\hline Innovation Culture & & & .876 \\
\hline Innovation is an underlying culture and not just a word & .753 & .624 & \\
\hline $\begin{array}{l}\text { Our senior managers are able to effectively cascade the innovation } \\
\text { message throughout the organization }\end{array}$ & .812 & .726 & \\
\hline $\begin{array}{l}\text { We have an innovation vision that is aligned with projects, } \\
\text { platforms, or initiatives }\end{array}$ & .727 & .644 & \\
\hline $\begin{array}{l}\text { This organization's management team is diverse in their thinking in } \\
\text { that they have different views as to how things should be done }\end{array}$ & .727 & .641 & \\
\hline $\begin{array}{l}\text { There is a coherent set of innovation goals and objectives that have } \\
\text { been articulated }\end{array}$ & .824 & .732 & \\
\hline Innovation is a core value in this organization & .817 & .728 & \\
\hline
\end{tabular}

\subsection{Test of Validity}

In order to establish convergent and discriminant validity of the construct used, there is need for an appropriate AVE (Average Variance Extracted) analysis (Fornell \& Larcker, 1981). There is convergent validity when items measuring the same construct correlate highly with each other (Campbell \& Fiske, 1959). We assessed convergent validity by ensuring there is adequate composite reliability, average variance extracted (AVE), and adequately high factor loadings as recommended (Komiak \& Benbasat, 2006; Hair et al., 2014). The criterion for establishing reliability is that the AVE measures should exceed .50 to ensure that, on the average, the measures share at least half of their variation with the latent variable (Fornell \& Larcker, 1981; Hjorth, 1994). As shown in Table 4, the AVE criterions was met. For discriminant validity, a test performed to see if the square root of every AVE value belonging to each latent construct is much larger than any correlation among any pair of latent 


\section{Macrothink}

International Journal of Human Resource Studies

ISSN 2162-3058 2019, Vol. 9, No. 3

constructs. AVE measures the explained variance of the construct. When comparing AVE with the correlation coefficient we actually want to see if the items of the construct explain more variance than do the items of the other constructs. Table 4 shows results of the AVE analysis. It can easily be seen that the AVE values are above 0.5 and, moreover, the square root of the AVE in the diagonal in Table 3 are above the correlation coefficients for each construct ensuring discriminant validity. For all the constructs, the items have high loadings, with majority above 0.50 therefore demonstrating convergent validity. Table 3 shows the correlation matrix and descriptive statistics of the measures used in the study. An examination of the skewness and kurtosis showed that measures used in the study met the normality assumption (Flora \& Curran, 2004).

Table 3. Correlation matrix and descriptive statistics

\begin{tabular}{llllll}
\hline Correlations & 1 & 2 & 3 & 4 & 5 \\
\hline 1. Innovation Culture & .78 & & & & \\
2. Transformational Leadership & $.401^{* *}$ & .72 & & & \\
3. Market Dynamism & $.452^{* *}$ & $.234^{* *}$ & .76 & & \\
4. Interaction External Environment & $.583^{* *}$ & $.463^{* *}$ & $.436^{* *}$ & .72 & \\
5. Dialogue & $.276^{* *}$ & .068 & .134 & $.299^{* *}$ & .77 \\
\hline Mean & 4.1357 & 4.0262 & 3.6667 & 3.8143 & 3.9865 \\
Standard Deviation & .50598 & .56080 & .75492 & .57876 & .61498 \\
Skewness & -.381 & -.856 & -.596 & -.022 & -.896 \\
Kurtosis & .496 & 1.703 & -744 & -.607 & 1.699 \\
Population & 210 & 210 & 210 & 210 & 210 \\
Average Variance Explained & .606 & .514 & .579 & .519 & .599 \\
\hline
\end{tabular}

\section{Hypothesis Testing}

The researcher used a multilevel hierarchical regression analysis to test the study hypotheses (Wang et al., 2011). According to Hox (2002), the use of this method of analysis is appropriate for cross sectional studies. Below is the results shown in Table 4. 
Table 4. Result of hierarchical regression analysis

\begin{tabular}{|c|c|c|c|c|}
\hline \multirow[b]{2}{*}{ Variables } & \multicolumn{4}{|c|}{ Innovation culture } \\
\hline & $\begin{array}{l}\text { Model A } \\
b \text { (t-values) }\end{array}$ & $\begin{array}{l}\text { Model B } \\
b \text { (t-values) }\end{array}$ & $\begin{array}{l}\text { Model C } \\
b \text { (t-values) }\end{array}$ & $\begin{array}{l}\text { Model D } \\
b \text { (t-values) }\end{array}$ \\
\hline \multicolumn{5}{|l|}{ Control variables } \\
\hline Constant & $4.614(25.857)^{* * *}$ & $3.096(10.419)^{* * * *}$ & $1.628(5.306)^{* * *}$ & $1.751(5.485)^{* * *}$ \\
\hline Number of employees & $-.167(-2.771)^{+}$ & $-.167(-2.659)^{+}$ & $-.182(-3.502)^{* *}$ & $-.104(5.485)^{* * *}$ \\
\hline Years of Firm Existence & $-.087(-1.274)$ & $-.167(-2.659)^{+}$ & $.014(.263)$ & $.021(.398)$ \\
\hline \multicolumn{5}{|l|}{ Independent variable } \\
\hline Transformational leadership (TL) & & $.387(6.135)^{* * *}$ & $.155(2.635)^{+}$ & $.095(1.420)$ \\
\hline \multicolumn{5}{|l|}{ Moderator variable } \\
\hline Market Dynamism (MD) & & & $.245(4.239)^{* * *}$ & $.257(4.418)^{* * * *}$ \\
\hline $\begin{array}{l}\text { Interaction with } \quad \text { External } \\
\text { Environment (IEV) }\end{array}$ & & & $.373(5.636)^{* * *}$ & $.400(5.878)^{* * *}$ \\
\hline Dialogue (D) & & & $.116(2.120)^{* *}$ & $.114(2.063)^{* *}$ \\
\hline \multicolumn{5}{|l|}{ Interaction Effects } \\
\hline $\begin{array}{l}\text { Transformational Leadership } \mathrm{x} \\
\text { MD }\end{array}$ & & & & $.256(4.54)^{* *}$ \\
\hline $\begin{array}{l}\text { Transformational Leadership } \mathrm{x} \\
\text { IEV }\end{array}$ & & & & $-.103(-1.693)^{+}$ \\
\hline Transformational Leadership x D & & & & $.114(2.063)^{* *}$ \\
\hline $\mathrm{R}^{2}$ & .042 & .190 & .455 & .466 \\
\hline F value & $4.488^{*}$ & $16.068^{* * *}$ & $28.192^{* * *}$ & $19.378^{* * *}$ \\
\hline$\Delta \mathrm{R}^{2}$ & & .14 .8 & 26.5 & .011 \\
\hline$\Delta \mathrm{F}$ value & & $37.640^{*}$ & $32.860^{* * *}$ & 1.409 \\
\hline Degrees of freedom & $2 / 207$ & $1 / 206$ & $3 / 203$ & $3 / 200$ \\
\hline
\end{tabular}

${ }^{+} p<.10, \stackrel{*}{p} p<.05,{ }^{* *} p<.01,{ }^{* * *} p<.001$

Table 4 (Model A) shows that the control variables explain $4.2 \%$ of the variance in innovation culture. The addition of the independent variable in Model B increased the variance in innovation culture to $19 \%\left(\Delta R^{2}=.14, \Delta F=37.640, p<.001\right)$. In Model $\mathrm{C}$, the moderation variables were introduced together with the independent variable, which increased $R^{2}$ by $26.5 \%(\Delta F=32.860, p<.000)$. The introduction of the interaction terms in Model D4 further increase $R^{2}$ by $11 \%(\Delta F=.011 p<.001)$. Model A shows that the control variable (Number of employees) had a negative but significant relationship with innovation culture $(b=-.087, p$ $<.010)$. Model B in Table 6 shows that transformational leadership is positively and significantly related to innovation culture $(b=.387, p<.001)$. We could therefore establish that, the first hypothesis, which stated that: There is a positive relationship between transformational leadership and innovation culture is supported. Similarly, when the moderators were added to the independent variables, it was seen that, transformational leadership had a positive relationship with innovation culture $(b=.155, p<.010)$, whiles market dynamism also had a positive and significant relationship with innovation $(b=.245, p$ $<.000)$. Similarly, interaction with external environment $(b=.373, p<.000)$ and dialogue $(b$ $=.116, p<.000$ ) had a positive and significant relationship with innovation culture. 


\section{$\triangle$ Macrothink}

International Journal of Human Resource Studies

ISSN 2162-3058

2019, Vol. 9, No. 3

Further, the moderating effect of Market dynamism and Organizational Learning capability (Interaction with external environment and Dialogue) were also assessed. The product of the transformational leadership and moderator variables showed that transformational leadership and market dynamism $(b=.256, p<.00)$ was significantly and positively related to innovation culture. From these results, we could establish that, the hypothesis two, which stated that, market dynamism will negatively moderate the relationship between transformational leadership and innovation culture is moderately supported. Transformational leadership and Interaction with external environment had a positive but a significant relationship with innovation culture $(b=-.103, p<.005)$ while transformational leadership and dialogue $(b=.114, p<.005)$ were positively and significantly related to innovation culture. Since interaction with external environment and dialogue are two dimensions of organizational learning capability, we could infer that there is partial support for the hypothesis that Organizational learning culture will moderate the relationship between transformational leadership and innovation culture.

\section{Discussion}

This research sought to find out the effect of transformational leadership on innovation culture. The results from the study showed that, the coefficient of this variable was positive and significantly related to innovation culture at $1 \%$ significance level once again conforming to the priori expectation of the study. The magnitude of the coefficient implies a $38.7 \%$ increase in innovation culture when transformational leadership was increased by a unit. A transformational leader articulates a compelling vision of the future, intellectually stimulate followers, recognizes individual differences and helps develop their strengths (Bass, 1985). Transformational leaders encourage employees to appreciate the importance of sacrificing their personal comfort and interest for the attainment of organizational goals. As a results in order to ensure innovation culture, organization's must adopt transformational leadership style as it allows leaders to use inspirational motivation and intellectual stimulation which are key for innovation. Transformational leaders promote creative ideas within their organizations and their behaviours are suggested to act as "creativity-enhancing forces"; individualized consideration "serves as a reward" for the followers, intellectual stimulation "enhances exploratory thinking", and inspirational motivation "provides encouragement into the idea generation process. Transformational leaders have the Charisma in their personality which is not only capable of creating imagination, long vision and meaning in the project; but also inspires value, respect and confidence in the team which in the end promote innovation culture among individuals. Hence, to promote innovation culture leaders and followers must raise one another to higher levels of morality and motivation as suggested by (Burns, 1978). These findings generally conform to the studies of Jung (2001), Jung, Chow \& Wu (2003) and Schein (1992) which reveal that, transformational leadership can enhance innovation culture. Transformational leadership has been found to be the most important in terms of impacting on innovation culture. This is because a transformational leader provides inspirational motivation and clearly establishes himself/herself as a role model who exudes trust and confidence (Cole et al, 2009; Bass, 1998).

From the results obtained, we could deduce that in creating the innovation culture, the 
transformational leader must exhibit the ability to let his/her follower understand the need to support their organizations to be efficient. The leader does this by ensuring that the followers receive mentoring and coaching to develop their skills and capabilities.

Through idealised influence, the transformational leader becomes a role model for his/her team and by that the learning capabilities of the organisation improves to positively support innovation culture. Employees lean from what they see of their leaders and it takes transformational leaders to make this happen. This learning opportunity given to employees can become a policy under a transformational leader and influence the promotion of innovation culture.

The market environment is an evolving one and therefore the transformational leader does not lose sight of its dynamism which influences innovation culture in an organisation. Transformational leadership style therefore relates positively to innovation culture when moderated by market dynamism. The element of competition, national economy, infrastructural development, improved communication channels, customer exposure and tastes are all factors that keep the market place dynamic, and it takes a transformational leader to keep his/her eye on the environment and adapt measures that positively influence the promotion of innovation in his/ her organisation.

\subsection{Implications}

The study also recommends that, leaders especially (transformational leaders) should be selfless, promote employee engagement, communicate to the employees with confidence and should be futuristic and inspirational based on the study. This is so important because the brightest and best ideas may not always come from the person sitting at the higher echelon of the organization. It is important to state that, the way and manner the organization is structured and evolves is significant because when people are only confined to rigid "boxes" in the name of organizational structures they are not able to get creative; rather working in project teams, for instance must be encouraged.

Also, the study reveals that leaders/managers in the Ghanaian service industry must actively engage their subordinates in the leadership process; especially for decisions focusing on customer innovation. This is necessary for many reasons. First, subordinates have better understanding of how the customer space is metamorphosing with respect to changing customer demands and perceptions on services. This coupled with their frequent interaction with customers at the service touchpoints means that they have a rich repertoire of information which could be used to make meaningful inputs during decision making processes on how to improve customer experience through innovation. Second, when leaders in the Ghanaian service industry indulge the viewpoint of their subordinates, resistance to innovation is less likely to ensue. This will greatly foster a conducive climate for the growth of an innovation culture. Typically, managers in Ghanaian organizations (as pertains in other Sub-Saharan African nations) tend to be authoritative in their leadership style (Beugre \& Offodile, 2001). However, the findings from study points to a growing need for them to have a rethink of their respective leadership approaches to include the viewpoint of their followers. This cannot be achieved through a passive approach. More importantly, Ghanaian service 
industry leaders need to actively pursue styles that engage and empower their followers to be part of the leadership process.

In essence, leaders within Ghana's service industry will need to adapt their leadership approach to styles that offer platforms for employees to become active followers. Active followership will breed knowledge sharing which then serves as a strong foundation for building innovative teams.

\subsection{Limitation and Directions for Future Research}

As with all works of original research, replication of this study would serve as a check on the reliability and generalization of the present findings. Also, researchers may wish to extend this study by undertaking more detailed analysis of the predictors found to be important in affecting innovation culture. One major implication of this study for industry practitioners and academia, as intimated by Aragon-Correa et al (2007), is that innovation, though a critical part of an organization's growth, is not just there for the taking but available to those organizations with the appropriate internal characteristics. This assertion, coupled with insights into other internal and external factors, will support the promotion of innovation culture in the service industry in Ghana.

\section{Conclusion}

In conclusion, this study attempted to examine the effect of transformational leadership style on innovation culture in the Ghanaian service industry; and further, the moderating role of market dynamism and organizational learning capability. The findings provided insight to the effect of changes in the market and the ability of firms to interact favourably with the external environment.

\section{References}

Ahmed, P. K. (1998). Culture and climate for innovation. European journal of innovation management, 1(1), 30-43. https://doi.org/10.1108/14601069810199131

Akbar, A. A., Sadegh, R., \& Chehrazi, R. (2015). Impact of transformational and transactional leadership style on employees' creativity and innovation. International Journal of Environmental Research, 12(4), 1109-1123.

Alegre, J., \& Chiva, R. (2008). Assessing the impact of organizational learning capability on product innovation performance: An empirical test. Technovation, 28(6), 315-326. https://doi.org/10.1016/j.technovation.2007.09.003

Amabile, T. M., Schatzel, E. A., Moneta, G. B., \& Kramer, S. J. (2004). Leader behaviors and the work environment for creativity: Perceived leader support. The Leadership Quarterly, 15(1), 5-32. https://doi.org/10.1016/j.leaqua.2003.12.003

Anderson, N., Potočnik, K., \& Zhou, J. (2014). Innovation and creativity in organizations: A state-of-the-science review, prospective commentary, and guiding framework. Journal of management, 40(5), 1297-1333. https://doi.org/10.1177/0149206314527128 
Avolio, B. J., \& Bass, B. M. (1988). Transformational leadership, charisma, and beyond. In J. G. Hunt, B. R. Baliga, H. P. Dachler, \& C. A. Schriesheim (Eds.), International leadership symposia series. Emerging leadership vistas (pp. 29-49). Lexington, MA, England: Lexington Books/D. C. Heath and Com

Bain, P. G., Mann, L., \& Pirola-Merlo, A. (2001). The innovation imperative:The relationships between team climate, innovation, and performance in research and development teams. Small Group Research, 32, 55-73. https://doi.org/10.1177/104649640103200103

Bass, B. M. (1999). Two decades of research and development in transformational leadership. European journal of work and organizational psychology, 8(1), 9-32. https://doi.org/10.1080/135943299398410

Bass, B. M., \& Riggio, R. E. (2006). Transformational leadership. Psychology Press. https://doi.org/10.4324/9781410617095

Bass, B. M., Avolio, B. J., Jung, D. I., \& Berson, Y. (2003). Predicting unit performance by assessing transformational and transactional leadership. Journal of applied psychology, 88(2), 207. https://doi.org/10.1037/0021-9010.88.2.207

Betancourt, R., \& Gautschi, D. (2001). Product innovation in services: A framework for analysis. In Advertising and Differentiated Products (pp. 155-183). Emerald Group Publishing Limited. https://doi.org/10.1016/S0278-0984(01)10008-8

Beugre, C. D., \& Offodile, O. F. (2001). Managing for organizational effectiveness in sub-Saharan Africa: A culture-fit model. International Journal of Human Resource Management, 12(4), 535-550. https://doi.org/10.1080/713769650

Bihani, P., \& Patil, S. T. (2014). A comparative study of data analysis techniques. International journal of emerging trends \& technology in computer science, 3(2), 95-101.

Burkus, D. (2011). Building the strong organization: exploring the role of organizational design in strengths-based leadership. Journal of Strategic Leadership, 3(1), 54-66.

Camps, J., \& Luna-Arocas, R. (2012). A matter of learning: How human resources affect organizational performance. British Journal of Management, 23(1), 1-21.

Carter, M. Z., Armenakis, A. A., Feild, H. S., \& Mossholder, K. W. (2013). Transformational leadership, relationship quality, and employee performance during continuous incremental organizational change. Journal of Organizational Behavior, 34(7), 942-958. https://doi.org/10.1002/job.1824

Chan, L. L., \& Idris, N. (2017). Validity and Reliability of The Instrument Using Exploratory Factor Analysis and Cronbach's alpha. International Journal of Academic Research in Business and Social Sciences, 7(10), 400-410. https://doi.org/10.6007/IJARBSS/v7-i10/3387

Chapman, R. L., Soosay, C., \& Kandampully, J. (2003). Innovation in logistic services and the new business model: a conceptual framework. International Journal of Physical Distribution 
\& Logistics Management, 33(7), 630-650. https://doi.org/10.1108/09600030310499295

Chemers, M. M. (1997). Leadership, change, and organizational effectiveness. University of California, Santa Cruz. Accessed on, 6.

Chen, Z., Lam, W., \& Zhong, J. A. (2007). Leader-member exchange and member performance: a new look at individual-level negative feedback-seeking behavior and team-level empowerment climate. Journal of applied psychology, 92(1), 202. https://doi.org/10.1037/0021-9010.92.1.202

Crossan, M. M., \& Apaydin, M. (2010). A multi-dimensional framework of organizational innovation: A systematic review of the literature. Journal of management studies, 47(6), 1154-1191. https://doi.org/10.1111/j.1467-6486.2009.00880.x

De Brentani, U. (2001). Innovative versus incremental new business services: different keys for achieving success. Journal of Product Innovation Management: An International Publication Of The Product Development \& Management Association, 18(3), 169-187. https://doi.org/10.1016/S0737-6782(01)00071-6

De Jong, J. P., \& Den Hartog, D. N. (2007). How leaders influence employees' innovative behaviour. European Journal of innovation management, 10(1), 41-64. https://doi.org/10.1108/14601060710720546

Dobni, C. B. (2008). Measuring innovation culture in organizations: The development of a generalized innovation culture construct using exploratory factor analysis. European Journal of Innovation Management, 11(4), 539-559. https://doi.org/10.1108/14601060810911156

Dvir, T., Eden, D., Avolio, B. J., \& Shamir, B. (2002). Impact of transformational leadership on follower development and performance: A field experiment. Academy of management journal, 45(4), 735-744. https://doi.org/10.2307/3069307

Eisenhardt, K. M., \& Martin, J. A. (2000). Dynamic capabilities: what are they?. Strategic management journal, 21(10-11), 1105-1121. https://doi.org/10.1002/1097-0266(200010/11)21:10/11<1105::AID-SMJ133>3.0.CO;2-E

Fernet, C., Trépanier, S. G., Austin, S., Gagné, M., \& Forest, J. (2015). Transformational leadership and optimal functioning at work: On the mediating role of employees' perceived job characteristics and motivation. Work \& Stress, 29(1), 11-31. https://doi.org/10.1080/02678373.2014.1003998

Flora, D. B., \& Curran, P. J. (2004). An empirical evaluation of alternative methods of estimation for confirmatory factor analysis with ordinal data. Psychological methods, 9(4), 466. https://doi.org/10.1037/1082-989X.9.4.466

Gallagher, K. S., Goodyear, R., Brewer, D., \& Rueda, R. (Eds.). (2013). Urban education: A model for leadership and policy. Routledge. https://doi.org/10.4324/9780203837337

Gilson, L. L., \& Shalley, C. E. (2004). A little creativity goes a long way: An examination of teams' engagement in creative processes. Journal of management, 30(4), 453-470. 
https://doi.org/10.1016/j.jm.2003.07.001

Gomes, G., \& Wojahn, R. M. (2017). Organizational learning capability, innovation and performance: study in small and medium-sized enterprises (SMES). Revista de Administração (São Paulo), 52(2), 163-175. https://doi.org/10.1016/j.rausp.2016.12.003

Graham, H. (2008). Marketing strategy and competitive positioning. Pearson Education India.

Gumusluoglu, L., \& Ilsev, A. (2009). Transformational leadership, creativity, and organizational innovation. Journal of business. https://doi.org/10.1016/j.jbusres.2007.07.032

Hegde, D., \& Shapira, P. (2007). Knowledge, technology trajectories, and innovation in a developing country context: evidence from a survey of Malaysian firms. International Journal of Technology Management, 40(4), 349-370. https://doi.org/10.1504/IJTM.2007.015757

Horwitz, I. B., Horwitz, S. K., Daram, P., Brandt, M. L., Brunicardi, F. C., \& Awad, S. S. (2008). Transformational, transactional, and passive-avoidant leadership characteristics of a surgical resident cohort: analysis using the multifactor leadership questionnaire and implications for improving surgical education curriculums. Journal of Surgical Research, 148(1), 49-59. https://doi.org/10.1016/j.jss.2008.03.007

Hoy, W. K., \& Miskel, C. G. (2008). The school as a social system. Educational administration: Theory, research, and practice, 1-40.

Ilies, R., Nahrgang, J. D., \& Morgeson, F. P. (2007). Leader-member exchange and citizenship behaviors: A meta-analysis. Journal of applied psychology, 92(1), 269. https://doi.org/10.1037/0021-9010.92.1.269

Jansen, J. J., George, G., Van den Bosch, F. A., \& Volberda, H. W. (2008). Senior team attributes and organizational ambidexterity: The moderating role of transformational leadership. Journal of Management Studies, 45(5), 982-1007. https://doi.org/10.1111/j.1467-6486.2008.00775.x

Jung, D. I., Chow, C., \& Wu, A. (2003). The role of transformational leadership in enhancing organizational innovation: Hypotheses and some preliminary findings. The leadership quarterly, 14(4-5), 525-544. https://doi.org/10.1016/S1048-9843(03)00050-X

Jyothibabu, C., Farooq, A., \& Bhusan Pradhan, B. (2010). An integrated scale for measuring an organizational learning system. The Learning Organization, 17(4), 303-327. https://doi.org/10.1108/09696471011043081

Kang, J. H., Solomon, G. T., \& Choi, D. Y. (2015). CEOs' leadership styles and managers' innovative behaviour: Investigation of intervening effects in an entrepreneurial context. Journal of Management Studies, 52(4), 531-554. https://doi.org/10.1111/joms.12125

Keller, R. T. (1992). Transformational leadership and the performance of research and development project groups. Journal of management, 18(3), 489-501. https://doi.org/10.1177/014920639201800304 
King, W. R. (2009). Knowledge management and organizational learning. In Knowledge management and organizational learning (pp. 3-13). Springer, Boston, MA. https://doi.org/10.1007/978-1-4419-0011-1_1

Kohli, A. K., \& Jaworski, B. J. (1990). Market orientation: the construct, research propositions, and managerial implications. The Journal of Marketing, 1-18. https://doi.org/10.1177/002224299005400201

Krause, G. A. (2003). Agency risk propensities involving the demand for bureaucratic discretion. Politics, policy and organizations: frontiers in the scientific study of bureaucracy, 41-72. https://doi.org/10.3998/mpub.17809

Li, Y., Wei, Z., Zhao, J., Zhang, C., \& Liu, Y. (2013). Ambidextrous organizational learning, environmental munificence and new product performance: Moderating effect of managerial ties in China. International Journal of Production Economics, 146(1), 95-105. https://doi.org/10.1016/j.ijpe.2012.11.008

Lunenburg, F. C. (2010, September). The decision making process. In National Forum of Educational Administration \& Supervision Journal (Vol. 27, No. 4).

Mbengue, A., \& Sané, S. (2013). Organizational learning capability: theoretical analysis and empirical study in the context of official development aid project teams. Canadian Journal of Administrative Sciences/Revue Canadienne des Sciences de l'Administration, 30(1), 26-39. https://doi.org/10.1002/cjas.1238

Miller, D., \& Friesen, P. H. (1983). Strategy-making and environment: the third link. Strategic management journal, 4(3), 221-235. https://doi.org/10.1002/smj.4250040304

Mittal, S., \& Dhar, R. L. (2015). Transformational leadership and employee creativity: mediating role of creative self-efficacy and moderating role of knowledge sharing. Management Decision, 53(5), 894-910. https://doi.org/10.1108/MD-07-2014-0464

Molina-Castillo, F. J., \& Munuera-Aleman, J. L. (2009). The joint impact of quality and innovativeness on short-term new product performance. Industrial Marketing Management, 38(8), 984-993. https://doi.org/10.1016/j.indmarman.2008.06.001

Northouse, P. G. (2015). Leadership: Theory and practice. Thousand Oaks, CA: Sage publications.

Ostrom, A. L., Bitner, M. J., Brown, S. W., Burkhard, K. A., Goul, M., Smith-Daniels, V., ... \& Rabinovich, E. (2010). Moving forward and making a difference: research priorities for the science of service. Journal of service research, 13(1), 4-36. https://doi.org/10.1177/1094670509357611

Para-González, L., Jiménez-Jiménez, D., \& Martínez-Lorente, A. R. (2018). Exploring the mediating effects between transformational leadership and organizational performance. Employee Relations, 40(2), 412-432. https://doi.org/10.1108/ER-10-2016-0190

Robbins, S. P., Judge, T., \& Breward, K. (2003). Essentials of organizational behavior (Vol. 7). 
Upper Saddle River, NJ: Prentice Hall.

Ryu, S., Park, J. E., \& Min, S. (2007). Factors of determining long-term orientation in interfirm relationships. Journal of Business Research,60(12), 1225-1233. https://doi.org/10.1016/j.jbusres.2006.09.031

Sattayaraksa, T., \& Boon-itt, S. (2018). The roles of CEO transformational leadership and organizational factors on product innovation performance. European Journal of Innovation Management, 21(2), 227-249. https://doi.org/10.1108/EJIM-06-2017-0077

Schein, E. H. (1992). Organizational culture and leadership. Jossey-Bass, San Francisco

Scott, S. G. \& R. A. Bruce (1994). Determinants of innovative behavior: a path model of individual innovation in the workplace, Academy of Management Journal, 37, pp. 580-607. https://doi.org/10.2307/256701

Tanriverdi, H. (2005). Information technology relatedness, knowledge management capability, and performance of multibusiness firms. MIS quarterly, 311-334. https://doi.org/10.2307/25148681

Tonkenejad, M. (2006). Two environment, two leadership styles. Tadbir, 17(174), 22-5.

Tsoukas, H., \& Mylonopoulos, N. (2004). Introduction: Knowledge construction and creation in organizations. British Journal of Management, 15(S1), S1-S8. https://doi.org/10.1111/j.1467-8551.2004.t01-2-00402.x

Van Knippenberg, D., \& Sitkin, S. B. (2013). A critical assessment of charismatic - transformational leadership research: Back to the drawing board?. The Academy of Management Annals, 7(1), 1-60. https://doi.org/10.5465/19416520.2013.759433

Wang, C. L., \& Ahmed, P. K. (2004). The development and validation of the organizational innovativeness construct using confirmatory factor analysis. European journal of innovation management, 7(4), 303-313. https://doi.org/10.1108/14601060410565056

Wang, H., Law, K. S., Hackett, R. D., Wang, D., \& Chen, Z. X. (2005). Leader-member exchange as a mediator of the relationship between transformational leadership and followers' performance and organizational citizenship behavior. Academy of management Journal, 48(3), 420-432. https://doi.org/10.5465/amj.2005.17407908

Wang, P., \& Rode, J. C. (2010). Transformational leadership and follower creativity: The moderating effects of identification with leader and organizational climate. Human relations, 63(8), 1105-1128. https://doi.org/10.1177/0018726709354132

Wang, P., Rode, J. C., Shi, K., Luo, Z., \& Chen, W. (2013). A workgroup climate perspective on the relationships among transformational leadership, workgroup diversity, and employee creativity. Group \& Organization Management, 38(3), 334-360. https://doi.org/10.1177/1059601113488163

Wayne, S. J., Shore, L. M., \& Liden, R. C. (1997). Perceived organizational support and leader-member exchange: A social exchange perspective. Academy of Management journal, 


\section{Macrothink \\ International Journal of Human Resource Studies \\ ISSN 2162-3058 2019, Vol. 9, No. 3}

40(1), 82-111. https://doi.org/10.2307/257021

Xenikou, A. (2017). Transformational leadership, transactional contingent reward, and organizational identification: the mediating effect of perceived innovation and goal culture orientations. Frontiers in psychology, 8, 1754. https://doi.org/10.3389/fpsyg.2017.01754

Yayavaram, S., \& Chen, W. R. (2015). Changes in firm knowledge couplings and firm innovation performance: The moderating role of technological complexity. Strategic Management Journal, 36(3), 377-396. https://doi.org/10.1002/smj.2218

Yeoh, K. K., \& Mahmood, R. (2013). The relationship between pro-innovation organizational climate, leader-member exchange and innovative work behavior: A study among the knowledge workers of the knowledge intensive business services in Malaysia. Business Management Dynamics, 2(8), 15-30.

Zhang, X., \& Bartol, K. M. (2010). Linking empowering leadership and employee creativity: The influence of psychological empowerment, intrinsic motivation, and creative process engagement. Academy of management journal, 53(1), 107-128. https://doi.org/10.5465/amj.2010.48037118

\section{Copyright Disclaimer}

Copyright for this article is retained by the author(s), with first publication rights granted to the journal.

This is an open-access article distributed under the terms and conditions of the Creative Commons Attribution license (http://creativecommons.org/licenses/by/4.0/). 